\title{
TEACHER TALK IN TEACHING WRITING INTERACTION OF TECHNICAL ENGINEEERING STUDENTS IN SMK SWASTA TELADAN MEDAN
}

\author{
(Ceramah Guru dalam Pengajaran Interaksi Menulis Siswa Teknik di SMK Swasta Teladan \\ Medan)
}

\section{Sutar Oktaviana Tampubolon}

Pos-el: Sutaroktaviana@gmail.com

tanggal naskah masuk 15 Maret 2019

tanggal akhir penyuntingan 16 Juni 2019

\begin{abstract}
Abstrak
Penelitian ini, fokus pada ceramah guru dalam pengajaran menulis yang dilakukan di kelas sebelas di SMK Swasta Teladan Medan dan untuk menggambarkan bagaimana kategori guru berbicara mempengaruhi proses belajar siswa selama menulis pengajaran ke kelas sebelas dari SMK Swasta Teladan di kelas sebelas. Medan. Dalam penelitian ini, FLINT digunakan untuk mengidentifikasi kategori-kategori pembicaraan guru yang terjadi selama proses pembelajaran. Selain itu, penelitian ini dilakukan pada bentuk penelitian deskriptif kualitatif dimana peneliti sebagai pengamat non-partisipan di kelas. Subjek penelitian ini adalah guru Bahasa Inggris sekolah menengah kejuruan dan siswa kelas XI SMK Swasta Teladan Medan. Dari data yang telah diambil, diperoleh bahwa kategori pembicaraan guru yang digunakan oleh guru dalam mengajar interaksi menulis pada siswa kelas sebelas di SMK Swasta Teladan Medan berkaitan dengan perasaan, memuji atau mendorong, bercanda, menggunakan ide-ide siswa, mengulangi respons siswa secara verbal, mengajukan pertanyaan, memberikan informasi, mengoreksi tanpa penolakan, memberikan arahan, dan mengkritik perilaku siswa. Selain itu, kategori pembicaraan guru yang digunakan juga telah terbukti membantu siswa memahami lebih baik tentang subjek dan memperoleh kontribusi siswa selama proses pembelajaran. Sebagai kesimpulan, peneliti telah menemukan bahwa guru yang mengajar menulis di kelas sebelas dari SMK Swasta Teladan Medan telah melakukan beberapa kategori pembicaraan guru dari FLINT.
\end{abstract}

Kata-kata kunci: Tutur guru, Menulis, FLINT

\begin{abstract}
This present, study focuses on the teacher talk in teaching writing which conducted in a eleventh grade classroom of SMK Swasta Teladan Medan and to describe how the categories teacher talk affect the students' learning process during the teaching writing to the eleventh grade of SMK Swasta Teladan Medan. In this research, the FLINT is used to identify the categories of teacher talk occur during the learning process. Moreover, this study is conducted on the form of descriptive qualitative research where the researcher as the non-participant observer on the classroom. The subject of this study is a vocational high school English teacher and the eleventh graders of SMK Swasta Teladan Medan. From the data that has been taken, it is obtained that the categories of teacher talk used by the teacher in teaching writing interaction in the eleventh grader of SMK Swasta Teladan Medan are deals with feeling, praises or encourages, jokes, uses ideas of students, repeats students response verbatim, asks question, gives information, corrects without rejection, gives direction, and criticizes student behavior. More over the categories of teacher talk used also have been proven to help the students understand better about the subject and elicit students' contribution during the learning process. In conclusion, the researcher has found that the teacher who teaches writing in an eleventh grade classroom of SMK Swasta Teladan Medan has performed some categories of the teacher talk from FLINT.
\end{abstract}

Keywords: Teacher talk, writing, flint 


\section{INTRODUCTION}

Generally, teacher talk is a part a of classroom interaction that also related with the students' learning activity. By performing the appropriate teacher instruction, teacher can motivate students to be actively involved in the speaking descriptive classroom since the speaking that has to be performed by students is in the form of monologue.

In teaching learning process, teacher actually has become an issue that has received attention from many researchers because it is a part of classroom interaction. Moreover, interaction is the collaborative exchange of thoughts, feelings or ideas, between two or more people (Dagarin, 2004: 128). Actually, for teacher and students, classroom is a place is used to organize teaching learning process. Classroom is a room in a school or college where groups of students are taught. Teaching learning process will creates if teachers and students have to establish a good interaction with others in Classroom. Brown (2000: 165) said that Interaction is the collaborative exchange of thought, feelings, or ideas between two or more people, resulting in a reciprocal effect on each other. On interaction, people get feedback each other also.

People use English to communicate in this globalization era that is why English becomes one of the languages that is needed to be taught in school. In learning English language, there are four skills should be taught to the students. They are speaking, listening, reading and writing. Each skill has an important role to complete someone's ability in using language. Writing is one of the skills that must be taught to the students, as Bruce (2008:2) states that to develop the writing skill of EAL (English as an additional Language) learners, it is now acknowledged by many that approaches to language teaching that focus on atomized units of language merely at sentence or clause level are not only inadequate but also possibly is misleading.

Based on the explanation above, the descriptive text is one of genre that must be mastered by students in learning English. And theoretically, according to Pardiyono (2007: 34) states that description is a type of written text, which has the specific function to give description about an object (human or nonhuman).

From the research findings from Markhamah, et al. (2012: 2) shows that students often feel frustrated when their English teacher ask them to compose a piece of writing because they do not understand well about grammar, student is lack of vocabulary and they have difficulties in expressing the information into the written form. Many students 
complain that they do not know how to write and they cannot link the sentences into coherence ideas. Actually, there are some various factors influencing this failure of education; such as inappropriate materials, inappropriate teaching methods or media, students' low motivation, etc. The students were not able to write and did not pay attention on the writing task. They do not know how to recognize their ideas in writing. They frequently get confused of what to write and how to start. For the students, writing is difficult because it is complex subject that involves organization of thought, the usage of English language and imagination.

English in vocational is relatively unexplored, especially from the view point of the teachers who are ultimately responsible for the student's learning. In general vocational school cannot be the same as senior high school. Learning styles, needs and students' characteristics are very different. Vocational students demand stricter disciplines of senior high school students. The worlds that require of vocational graduated students, vocational has a readymade expertise in the world of work. Essentially, the teaching learning process has evident in student learning ability difference in the classroom. Therefore, it is vital that teachers focus more to the needs of their individual students. The teacher should not only focus on material achievement when teaching, they should also be able to treat the student individuals by the language used or “Teacher talk".

Many researchers have tried to analyze the teacher talk related to strategy, question, turn-taking, etc using various devices of analysis such as Flanders' Interaction Analysis Categories (FIAC), Foreign Language INTeraction (FLINT), Brown Interaction Analysis System (BIAS). Among those famous devices of analysis this study tries to carry out the Foreign Language INTeraction (FLINT) as the instrument to process the information and analyze the teacher talk happens in the classroom. FLINT is an instrument, which is used to describe the verbal communication in the classroom. This theory is developed by Moskowitz. Moskowitz divided teacher talk into two categories, including indirect influence and direct influence. In each category, there are some points, which describe certain interaction event that we can find in the classroom.

Regarding the importance of teacher talk in teaching learning process, this study is intended to analyze the teacher talk in teaching writing interaction of technical engineering students in smk swasta teladan medan. 


\section{REVIEW OF LITERATURE}

Teachers talk is an indispensable part of foreign language teaching in organizing activities, and the way teachers talk not only determines how well they make their lectures, but also guarantees how well students will learn. Appropriate teacher talk can create harmonious atmosphere and at the same time promotes a more friendly relationship between teachers and students, and consequently creates more opportunities for interactions between teachers and students.

According to Moskowitz's FLINT (Foreign Language Interaction) analysis system in Brown (2001:177), teacher talk has eleven categories which enable to be analyzed in classroom interaction. Those eleven categories of teacher talk are divided into two kinds of influence; indirect and direct influences.

As known, a classroom is a formal environment where interaction between teacher and students take place. The classroom is the place where teachers and students come together and teaching learning process is supposed to happen. In the classroom there should be an interaction done by teachers and students. Interaction comes in many shapes and fashions. For instance: repeating after teacher, answering a display question, acting out a dialogue, and discussing possible solutions to a task.
Writing is one of language skills to convey thoughts, ideas, desires, and feelings, which performed through written forms. Writing is not as simple as imagined, because we are more able to speak than to write. According to Qui (2011) as cited by Ritonga (2014: 7) states that writing is as the process of transforming the material discovered by research inspiration, accident, trial or error, or whatever into a message with definite meaning. There are five genres applied in Junior High School, i.e. descriptive, recount, procedure, and narrative. The genre this research focused on is descriptive text.

According to Pardiyono (2007:34) states that description paragraph was a type of written text, in which has the specific function to describe about an object (living or non-living things) and it has the aim that was giving description of the object to the reader clearly. Teaching refers to the process of imparting knowledge and skills from a teacher to a learner. Transferring knowledge to students is not an easy way to do. It must be done in creative way by every teacher to get the students' attention so that every message can be delivered successfully.

According to Biddle and Rossi (1966: 5), state that educational media are those used to support the processes of education, whereby teachers attempt to 
induce learning in students. Media plays an important role in the process of teaching and learning.

There are some system of classroom interaction analysis which are designed in years before 2000s namely (Flanders' Interaction Analysis Categories (FIAC) (Flanders:1970 and Foreign Language INTeraction (FLINT)until after 200s namely Brown Interaction Analysis System (BIAS) (Brown:2001). The researcher only focus to use FLINT Theory

This model is helpful in developing interactive language teaching sinceit gives teachers a taxonomy for observing other teachers. Also, it gives teachers a framework for evaluating and improving their own teaching. Last, it helps to set a learning climate for interactive teaching. When observing a language teacher by using FLINT model, it is possible to get more ideas about how to initiate interaction in class.

\section{RESEARCH METHODOLOGY AND FINDINGS}

Creswell (2009) explains research designs as the plans and the procedures for research that span the decisions from broad assumptions to detailed methods of data collection and data analysis

\section{Procedures of Analyzing the Data}

To describe the interaction in this case teacher talk that occurs during English teaching and learning process the researcher used some techniques as follows:

\section{Observation}

Observation is one of the techniques of collecting data which is from direct experience. Observation is useful technique which provides evidence about additional information about the topic being discussed. (Yin, 2003:93) The objective of observation is to explain the situation being investigated activities, person or individual who are involved in an activity and the relationship among them. By doing observation, the researcher has the opportunity to know and understand the situation which occurs in teaching learning process, to see things that might be un conciously missed, and to obtain information that might not be obtained from other techniques.

In this study, the observation was carried out to the teacher talk. This is a nonparticipant observation, it means that although the researcher was present in the classroom,she did not participate in the activities. She just sat on the back of the classroom, observed and recorded classroom interaction. The classroom was observed during the speaking analytical exposition learning process where the teacher taught 47 students in a class. The researcher observed the teacher using observation checklist made by the researcher. While doing the observation the researcher employed field notes to note direct information found in the classroom 


\section{Video Recording}

Nunan (1992) argues the use of recorded data that allows for the preservation of the primary data, for example in the form of audio and video recordings. Video recording was applied as the technique for capturing natural interaction in the classroom in detail. The researcher recorded the process of teaching and learning English that is aimed to get accurate information about the categories of teacher talk occur during the language learning and the way teacher talk affects student's speaking ability.

\section{DATA ANALYSIS}

After collecting the data fromthe result of the observation, the data will be analyzed inductively with the following steps:

1. Transcribing the spoken data

The researcher rewrote the data from video recording into the written form.

2. Reducing the data

The researcher chose the data that were relevant to the topic.

\section{Data coding}

The researcher gave code to the data so that the researcher found out easily to rechecked the data. The researcher classified the data to answer the problem of the study. The researcher classified the data using the Foreign Language INTeraction (FLINT)

4. Drawing conclusion from the response

The researcher described the teacher talk using Foreign Language INTeraction (FLINT) based on the data.

\section{Findings}

The table presents the categories of indirect influence teacher talk used by the teacher during teaching and learning process in two meetings. It can be seen in the following table below:

Table 1. The result of indirect influence teacher talk

\begin{tabular}{|l|c|}
\hline INDIRECT INFLUENCE & RESULT \\
\hline Deals with feelings & 1 \\
\hline Praises or encourages & 20 \\
\hline Jokes & 3 \\
\hline Uses ideas of students & 7 \\
\hline $\begin{array}{l}\text { Repeats students response } \\
\text { verbatim }\end{array}$ & 11 \\
\hline Ask question & 30 \\
\hline Total & 72 \\
\hline
\end{tabular}

From the table above, it can be seen that the teacher used all categories of indirect influence teacher talk in teaching writing. The teachers used the indirect influence teacher talk for the following purposes: dealing with feeling, praising/encouraging, joking, using students' ideas, repeating students' response, and asking questions. For the praises or encourage 20 and the ask 
question 30 was the most type of teacher talk from the observation.

\section{b Direct Influence}

The table presents the categories of direct influence teacher talk used by the teacher during teaching and learning process. It can be seen in the following table below:

Table 2. The result of direct iinfluence teacher talk

\begin{tabular}{|l|c|}
\hline DIRECT INFLUENCE & RESULT \\
\hline Gives Information & 25 \\
\hline Corrects information & 1 \\
\hline Gives Directions & 18 \\
\hline $\begin{array}{l}\text { Criticizes students } \\
\text { behavior }\end{array}$ & - \\
\hline $\begin{array}{l}\text { Criticizes students } \\
\text { response }\end{array}$ & - \\
\hline Total & 46 \\
\hline
\end{tabular}

The table above illustrates that the teacher produced four categories of direct influence teacher talk. The direct influence teacher talk used by the teacher were gives information, corrects without rejection, gives directions, and criticizes student behavior.

\section{CONCLUSION AND SUGGESTIONS}

\section{Conclusions}

The findings of the study lead to the following conclusion:

The categories of teacher talk in the English class at SMK Swasta Teladan Medan are the indirect teacher talk and direct teacher talk. The indirect influence consists of "deals with feelings, praises/encourages, jokes, uses ideas of student, repeats students response verbatim, and asks questions". While direct influence consists of gives information, corrects without rejection, gives directions, criticizes students behavior, and criticizes or student response, it means that the teacher intentionally lets the students to respond in their own way and encourage them to do so.

The ten categories of teacher talk that were employed by the teacher during the teaching learning process affected the students in learning paticularly asks question and praises/encourages (indirect influence) and gives information and gives directions (direct influence). It is shown from the observation result during the larning process all of students were well involved.

\section{Suggestions}

Based on the data findings and what this research intended to, it is suggested that:

English teachers should pay attention to their either indirect nor direct talk since it would determine the way their students involve and participate in classroom activities. The teacher should increase their talk it is amount of indirect influence or direct influence, which includes acceptance of students' feeling, praises and encouragement, and acceptance 
or uses of the students' ideas. This is important because such talk has strong motivational impact on the students. They need to be encouraged, paid attention to, and tolerated, but also criticized and reminded. In that way, their learning will be more effective.

Further research in classroom practice should consider teacher talk as an important part that contribute the whole classroom process and not to override its significance by paying attention too much on the material only.

\section{REFERENCES}

Batko, A. (2004). When Bad Grammar Happens to Good People: How to Avoid Common Errors in English. Franklin Lakes, NJ: Career Press.

Brown, H. D. (2007). Principles of Language Learning and Teaching(5th edition). USA: Pearson Education, Inc.

Burns. A and Claire, S. (2003). Clearly Speaking: Pronunciation in Action for Teachers. Sydney: Macquarie University.

Byrne, D. (1999). Teaching Oral English (New Edition). Mishawaka: Longman Publish Group.

Cameron, L. (2001). Teaching Language to Young Learners. Cambridge: Cambridge University Press.
Chaudron, C. (1998). Second Language Classroom: Research on Teaching and Learning. Cambridge: Cambridge University Press.

Cook, V. (2000). Second Language Learning and Language Teaching (2nd Edition). Beijing: Foreign Language Teaching and search Press.

Creswell. (2009). Educational Research: Planning, Conducting, Evaluating Quantitative and Qualitative Research (3rd edition). New Jersey: Pearson Education International.

Harmer, J. (2000). How To Teach English. Beijing: Foreign Language Teaching and Research Press.

Harmer, J. (2001). The Practice of English Language Teaching (3rd Edition). London: Longman.

Kayi, Hayriye. (2016). Teaching Speaking: Activities to Promote Speaking in a Second Language. The Internet TESL Journal, Vol. XII, No. 11, May 2016.

Kiasi, M. A \& Fatemeh, H. The Importance of 'Teacher Talk' in Teaching EFL Writing. Porta Linguarum. Iran: Payame Noor University.

Long, M. \& Sato, C. (1983). Classroom Foreigner Talk Discourse: Forms and Functions of Teachers ${ }^{\text {ee }}$ questions. In Seliger and Long (eds). Classroom Oriented research in Second Language Acquisition. Newbury House. 